\title{
Strategy Development of Regional Credit Guarantee Company
}

\author{
Jodi Septiadi Akbar ${ }^{1}$, Arif Imam Suroso ${ }^{1}$, Rokhani Hasbullah ${ }^{2}$ \\ ${ }^{1}$ IPB University, School of Business, Jl. Raya Pajajaran Bogor, Indonesia \\ ${ }^{2}$ Department of Mechanical Engineering and Biosystems, Faculty of Agricultural Technology, IPB University, \\ Jl. Agatis kampus IPB Dramaga, Bogor 16880 \\ Corresponding Author: Jodi Septiadi Akbar
}

\begin{abstract}
Micro, small and medium enterprises (MSME) have difficulty obtaining access to bank financing. One of these difficulties is due to the limited collateral as a credit requirement. The government overcomes the problem by forming a credit guarantee company to replace the collateral requirements. One company that runs a credit guarantee business is PT. Jamkrida Riau (Jamkrida Riau). This research aims to: 1) identifying environmental factors that affect the management of internal and external in Jamkrida Riau; 2) analyze alternatives in developing Jamkrida Riau business strategy; 3) priority strategy formulated exact in business development Jamkrida Riau in the future. This study using analysis tools an internal factor evaluation matrix (IFE), external factor evaluation matrix (EFE), Internal-External matrix (IE), SWOT matrix and QSPM matrix. The results showed that an alternative strategy lead in developing its business in sequence was 1) internal risk control in the process of credit guarantee; 2) capacity building capital participation of regional governments or other investors; 3) improve cooperation with other institutions related to credit guarantee; 4) an increase in information technology adaptation; 5) giving assistance to MSME; 6) product development of ensuring that corresponds to focus effort; 7) marketing product development
\end{abstract}

Keywords: bank, credit guarantee, micro and small enterprises (MSMEs), MSMEs credit, strategy.

\section{INTRODUCTION}

Micro, small and medium enterprises (MSME) are the largest business sector in the Indonesian economy. The number of businesses included in the MSME sector is 62 million people and contributes $57.6 \%$ of the total national Gross Domestic Product (GDP) in 2018 (Kemen KUKM, 2019). Open competition between businesses will increase competition and affect planning of any business operators to be competitive.

The existence of these MSME encounter problems in developing their business scale. Wardiyah (2014) states that MSME businesses face the various problems commonly found in, field especially the problem of a shortage of capital, lack of access to MSME, banking businesses limited non-bank financial institutions banks to receive credit for, and limited MSME in maintaining product quality.

One form of government to solve the problem is to provide services credit guarantee. Credit guarantee business sector in Indonesia is run by state-owned companies (BUMN), private companies and regional-owned companies (BUMD). Credit guarantee according to Anwar and Pranoto (2015) is an activity the security to the creditor over credit or funding disbursed to debtor due to the requirements set by a creditor. Credit guarantee company as a security to bear payment from the debtor to the insured when borrowers unable to fulfill 
its obligation under the pact agreed (Azharfan and Ibrahim, 2020). Zulaekhah (2018) states that credit guarantee is done with the delegation of the assignee or of the fulfillment of obligations a debtor to credit guarantee company. Wahyu and Fatonah (2017) said that credit guarantee involving three parties, some of them are parties can be guaranteed, the underwriters and parties that provides a credit facility.

Increase the amount of company credit guarantee was affected by economic growth in Riau Province. This economic conditions are also affecting the banking credit in Riau Province, where bank credit disbursement in Riau Province reached IDR 106.77 trillion in 2019 (BPS Provinsi Riau, 2020). The portion of MSME credit disbursement in Riau Province in the same year reached IDR 24.60 trillion (Bank Indonesia, 2020). Based on total of MSME credit distribution, Jamkrida Riau achieved credit guarantee IDR 882.520 billion or $3.59 \%$ of the total MSME credit market share in Riau Province in 2019.

The potential of MSME sector that can be used by Jamkrida Riau in improving MSME credit guarantee businesses was the agricultural sector, trade and the services sector. The agricultural sector is the largest contributing to MSME credit in Riau Province with a contribution reached $41.28 \%$, followed by the trade and the services sector each contribute $38.89 \%$ and $8.21 \%$ (Bank Indonesia, 2020). These business sectors are still not optimally accommodated by credit guarantee services because of credit guarantee services are not widely known by the public. People are more aware with insurance services than guarantee services.

Although the growth of MSME credit guarantee at Jamkrida Riau has increased, company financial performance of Jamkrida Riau has fluctuated in recent years. This can be seen from the amount of company revenue that comes from net guarantee fees (IJP), which decreased in 2019. The decreased income was followed by an increase in the number of claims that the company had to pay and the amount of the company's receivables. This condition caused the company to experience a decrease in revenue so that it suffered a loss of IDR 3.854 billion in 2019. The conditions of profit/loss received by Jamkrida Riau is presented in Table 1.

Table 1. The increasing trend of PT Jamkrida Riau credit guarantee in 2017-2019

\begin{tabular}{|l|l|l|l|l|}
\hline \multirow{2}{*}{ Indicators } & \multicolumn{4}{|c|}{ Year } \\
\cline { 2 - 5 } & Type of unit & $\mathbf{2 0 1 9}$ & $\mathbf{2 0 1 8}$ & $\mathbf{2 0 1 7}$ \\
\hline Amount of credit & Rp billion & 1.859 & 955 & 299 \\
\hline Revenue & Rp billion & 5,596 & 8,265 & 5,605 \\
\hline Pembayaran Klaim & Rp billion & 6,782 & 5,928 & 1,506 \\
\hline Account payable & Rp billion & 6,049 & 3,341 & 0,314 \\
\hline Amount of MSME's & Unit & 12.041 & 8.045 & 4.530 \\
\hline \multicolumn{5}{|c}{ Source : PT Jamkrida Riau Annual Report (2020) } \\
\hline
\end{tabular}

Several problems faced by the company become consideration in evaluating a company planning proper strategy. Business strategy planning is an effort in improving the company performance. The formulation is considering several aspects of the company's strategy, such as the government laws and policies, market opportunities and external threats, company strengths and resources, the competency and the ability to compete (Putri, et.al 2020).

Strategy and planning a business decision company it is developed based on the analysis of the company in internal and external business environment, consisting of strengths, weaknesses, opportunities and threats. This study aims to analyze the business development strategy of Jamkrida Riau using SWOT analysis based on the scores obtained from the Internal Factor Evaluation (IFE) matrix analysis and External Factor Evaluation (EFE) matrix analysis. It's matched through the InternalExternal matrix to see the company's position. Alternative strategies resulting from SWOT matrix then sorted based on their strategic priorities using the Quantitative Strategy Planning Matrix (QSPM) matrix analysis.

\section{METHODS}

This research was conducted in October-December 2020 at Jamkrida Riau, which is located at Sudirman Street No. 25 
Pekanbaru. This study identifies internal and external factors that are owned by the company.

The kind of data that used in this research are primary data and secondary data. The primary data represents data obtained from direct meetings with the speakers as the result of research (Nugroho et.al, 2015). The data and information used in the research obtained by observation, interviews, and filling the questionnaires by the company management. Secondary data used in this research based on company documents and other supporting information from literature, such as research journals and other supporting data.

The business environment analysis is the relationship between the environment in a business that has links to (Lapod, 2016). Companies generally influenced by two environments, namely the internal environment and the external environment. The internal environment is a strength and weakness owned by organization in activity that can be controlled by the company (David, 2010). The external environment is a variable consisting of opportunities and threats that are outside organization in the short term and cannot be controlled by the organization. The external environment is a factor of opportunities and threats consisting of several aspects, including economy, socio-culture, demography, and environment, politics and law, governance, technology and competitive trends that benefit or harm the company in the future. Weighting of internal factors using the Internal Factor Evaluation (IFE) matrix and external factors using the External Factor Evaluation (EFE) matrix. The scores from the IFE and EFE weighting matrices are used to see the company's position in the Internal-External (IE) matrix quadrant.

After finding the position of the company quadrant in IE matrix, the formulation of alternative strategy continues by using a SWOT matrix. SWOT analysis used to identify the strengths, weaknesses, opportunities and threats faced by a company (Abiyyu et.al, 2020). The SWOT analysis consists of questions that saw the area that will help (strengths and opportunities) as well as areas that will harm the company (opportunities and threats) (Andreas, 2019). SWOT analysis provided the basis for discussed to a greater depth, decision making, and innovation in business environment (Osterwalder and Pigneur 2010). The resulting strategy in the SWOT matrix divided into four parts, including: 1) SO (Strength-Opportunity) Strategy; 2) WO (Weakness-Opportunity) Strategy; 3) Strategy WT (WeaknessThreats) and; 4) ST (Strength-Threats) Strategy.

Based on the alternative strategy that showed from the four sections of the SWOT matrix, the strategy formulation determines the priorities of strategy. Determination of priority strategies from several predetermined alternative strategies obtained from the earlier stages is the final stage in strategy formulation. Priority strategy aims to execute the strategy as specified in a focused way so that the results of the end of the strategic planning are optimal (Annisa, 2015). Analysis of priority strategy is using the QSPM (Quantitative Strategic Planning Matrix) matrix. QSPM analysis is carried out by providing an assessment of each of the alternative strategies formulated against the strategic factors that have been previously identified (Editiyanto, 2014). The QSPM matrix determines attraction relatively of various strategies which built on important internal and external success factors (David 2010).

\section{RESULTS}

\section{Analysis of Internal and External Factors}

Internal and external strategic factors identification is carried out by interview and observation. The identification of strategic factors is carried out to determine the main factors that affect the performance of a credit guarantee company. Identification of internal and external factors can use the external factor evaluation matrix (EFE) and the internal factor evaluation matrix (IFE) (Haq and Singgih, 2019). Internal 
environmental factors consisting of management aspects, marketing, finance, production/operations, research and development, as well as information management systems. The external environment consisting of opportunities and threats, including economic, social, cultural, demographic and environmental aspects, political, governance and legal aspects, technological aspects and competitive aspects (David, 2010). Internal factors in this research analyzed five factors of strength and five factors of weakness, while external factors consisting of five factors of opportunity and five factors of threat.

Identification of internal factors found several factors that influence the credit guarantee business at regional credit guarantee companies. Strength factors include the position of the company as a Regional Owned Enterprise (BUMD), the value of the company's assets that are experiencing growth, the company's ability to guarantee MSME credit, business segmentation that receives credit guarantee and the company's HR development program that continues to grow. The weakness factors that become obstacles in the company include the lack of business capital, the burden of operating costs that continues to increase, the lack of utilization of technology and information devices, the limited number of human resources, and the company's limited reach.
External environmental analysis identifies several factors of opportunities and threats that could affect the company's business. External factors affecting opportunities include economic growth in Riau province, business development, government support in developing MSME, opening up cooperation in the Riau province, and the use of technology and information in business activities. External factors of threats identified in this study are the ability to pay claim risk, the level of competition in similar industries, the risk of asymmetric information, company limitations caused by regulations, and limitations in information regarding credit guarantee.

Table 2. The internal factor evaluation matrix of Jamkrida Riau

\begin{tabular}{|l|l|l|l|}
\hline Strength & Weighted & Rating & Score \\
\hline $\begin{array}{l}\text { Positions as a regional } \\
\text { owned enterprises }\end{array}$ & 0,143 & 3 & 0,429 \\
\hline Positive growth of assets & 0,090 & 4 & 0,360 \\
\hline $\begin{array}{l}\text { Cooperation in risk } \\
\text { mitigation }\end{array}$ & 0,125 & 3 & 0,375 \\
\hline Specific market targets & 0,101 & 3 & 0,303 \\
\hline $\begin{array}{l}\text { Development on HR } \\
\text { programme }\end{array}$ & 0,086 & 3 & 0,258 \\
\hline Weakness business & 0,108 & 2 & 0,216 \\
\hline $\begin{array}{l}\text { limitation of } \\
\text { capital }\end{array}$ & 0,096 & 2 & 0,192 \\
\hline $\begin{array}{l}\text { the increases of operational } \\
\text { cost }\end{array}$ & 0,073 & 2 & 0,146 \\
\hline Limitation in technology & 0,085 & 1 & 0,085 \\
\hline Limitation of HR quantity & 0,093 & 2 & 0,186 \\
\hline $\begin{array}{l}\text { Limitation of business } \\
\text { coverage }\end{array}$ & $\mathbf{1}$ & & $\mathbf{2 . 5 5 0}$ \\
\hline
\end{tabular}

Table 3. External factor evaluation matrix analysis of Jamkrida Riau

\begin{tabular}{|c|c|c|c|}
\hline Opportunities & Weighted & Rating & Score \\
\hline economic growth in Riau Province & 0.113 & 3 & 0.395 \\
\hline development of the credit guarantee business sector and supporting business fields & 0.095 & 3 & 0.301 \\
\hline the support of the Regional Government to increase the empowerment of unions and MSMEs & 0.102 & 3 & 0.323 \\
\hline cooperation with other banking / non-bank partners & 0.090 & 3 & 0.302 \\
\hline the use of Technology and Information in the business activities & 0.062 & 3 & 0.175 \\
\hline \multicolumn{4}{|l|}{ Threats } \\
\hline ability to pay credit / claim risk & 0.137 & 3 & 0.445 \\
\hline fairly level of competition & 0.094 & 2 & 0.213 \\
\hline the emergence of asymmetric information & 0.088 & 3 & 0.243 \\
\hline limited scope of the company in regulation & 0.081 & 3 & 0.201 \\
\hline limited knowledge and information about credit guarantees & 0.123 & 3 & 0.339 \\
\hline Total score matrix EFE & 1 & & 2.937 \\
\hline
\end{tabular}

The results of the identification of IFE matrix showed that the main strength factor affecting the credit guarantee business is the company's position as a BUMD, while the biggest weakness factor faced by Jamkrida Riau company is a limited business capital. As a BUMD company, the company gets a special position in establishing partnership relationships between BUMD companies, 
such as Regional Development Banks which control the share of Jamkrida Riau credit guarantees up to 90 percent. However, as a BUMD company, the company is constrained by increasing capital. Companies have difficulty obtaining additional business capital due to a long bureaucratic process (Anwar and Pranoto 2015). The IFE matrix analysis showed that the highest score of the strength and weakness factors is 4.0 and the lowest score is 1,0 with an average of 2,5 (David, 2010).

The results of EFE matrix showed that the main opportunity factor in developing the credit guarantee business is the economic growth of Riau province. Economic growth is one aspect that affects the business growth of Jamkrida Riau company and the quality of bank credit. The biggest threat factor that can affect the company's performance is the ability to pay credit/claim risk. Payment of credit risk/claim is also influenced by the quality of bank credit. The quality of bank credit is based on the value of the Non-Performing Loan (NPL). An increase in the NPL value of banking partners can affect the increase in claims submitted to the company. The results of the internal and external factor analysis are shown in Table 2 and Table 3.

\section{Alternative strategies for developing a credit guarantee company}

The analysis stages of selecting the company's strategy alternatives use Internal-External (IE) matrix and SWOT matrix. IE matrix identifies nine corporate strategy cells which will be established in three main strategies (Wibowo, 2009). IE matrix combines the $\mathrm{X}$ axis as the total score of IFE matrix and the $\mathrm{Y}$ axis as the total score of EFE matrix. The resulting scores on the IFE matrix and the EFE matrix were respectively 2,55 and 2,94 . IE matrix showed that the position of the company is in cell V. A company in that cell position carry out hold and maintain strategy. The results of the internal-external analysis suggest to apply market penetration strategy and product development strategy. Both of these strategies are part of the type of intensive strategy, where these strategies are a form of intensive efforts to improve the competitiveness of the company through the products developed (David, 2010). InternalExternal Matrix analysis is shown in Figure 2.

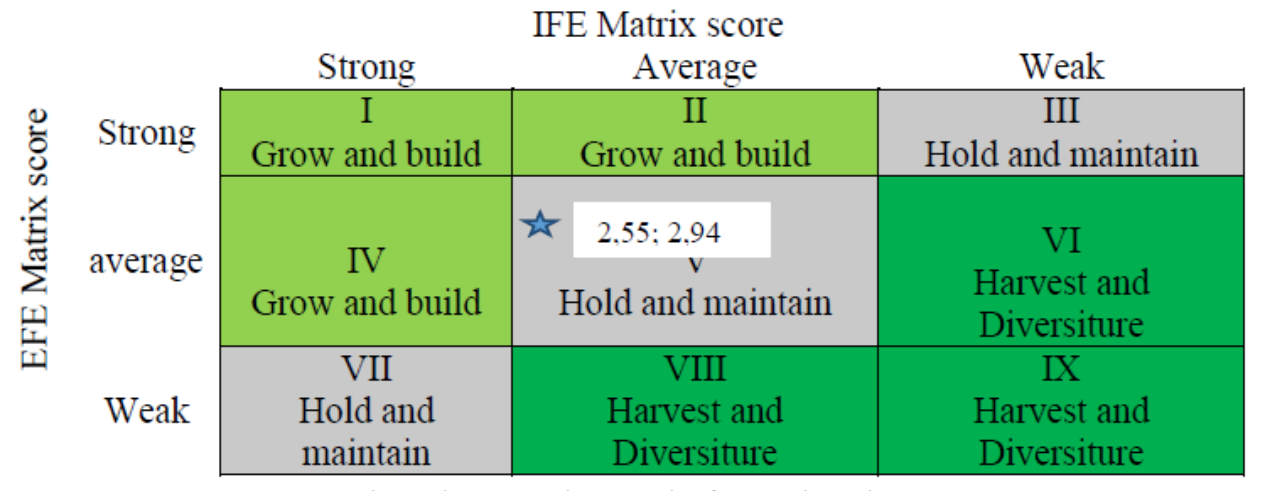

Figure 2. IE Matrix analysis of Jamkrida Riau
The result of SWOT analysis matrix is divided into four parts, namely: 1) SO (Strength-Opportunity) strategy is carried out by taking advantage of opportunities that come from external factors and maximizing the strengths they have; 2) The WO (Weakness-Opportunity) strategy serves to help organizations improve weaknesses using existing opportunities from external opportunities; 3) The WT (Weakness-Threats) strategy is a company step in minimizing internal and external threats; 4) ST (Strength-Threats) Strategy is a strategy used by the company to overcome threats by using the resources available in the company as a strength.

The results of the SWOT analysis showed several alternative strategies that 
formulated based on previously identified internal and external factors. SO (StrengthOpportunity) strategies relate to market penetration and product development. Market penetration strategy is a strategy used to find a wider market share than the marketing strategies that have been carried out previously. Strategies that can be done are to increase the number of marketers, the number of advertisements, extensive sales promotion, or increase publicity efforts (David, 2010). This strategy can be applied by the company considering the market share of credit guarantee services is still very wide open for companies where in 2019 the number of MSME in Riau province totaled 286.668 businesses, while the company only guaranteed 4,20 percent of the total UMKM. Companies can take advantage of the SO strategy by harnessing the greatest strengths to maximize opportunities, by undertaking a partnership strategy with the government to develop marketing distribution (Sulastri, 2018).

Product development strategy is a strategy to increase the product sales by modifying products company currently served (David, 2010). This strategy can be applied to industries that continue to experience growth, where competitors have similar products but are better or cheaper. Product development strategies can be developed by looking at the potential of a region but still following the applicable regulations (POJK No.6/POJK.05/2014 concerning the management of credit guarantee companies). Companies can develop products that suit the credit needs of UMKM in Riau province, based on the business sector managed together with bank partners that provide credit. Business sectors that obtain MSME loans in Riau province are divided into three business sectors, including plantation business, trading business and service sector (Bank Indonesia, 2020). The business sector could be considered by the company in developing the credit guarantee products, so as to provide maximum benefits to MSME as consumers and banks as partners.
The WO strategy (weaknessopportunity) has produced two strategic expressions. The first formulation of this strategy is to increase company capital investment capability. Increasing capital capacity expected to correct the company's current shortcomings, such as lack of technology and information infrastructure, as well as improve the quantity and quality of human resources with business development and applicable regulations. Increasing the capital investment of credit guarantee companies can increase the guarantee capacity that the company can have, so that the company can expand its product marketing.

Second, improve adaptation to better technology and information devices for expand the scope of credit guarantee services. In addition, the company strives to improve the quality of services by developing the ability to use technology and information, so as to provide faster and more accurate services according to the needs of banking partners. The implementation of this strategy must also be strengthened by developing the skills and capabilities of human resources for technology development.

Strength-threat (ST) strategy has produced two alternative strategies. Strategies to strengthen cooperation with other institutions in risk management. This kind of cooperation is related to controlling the company's operational costs and improving the company's ability to pay risk by cooperating with reinsurance companies, so it can be reduce the company expenses.

In addition, another strategy is providing consulting and education services to MSME. It related to credit guarantees to improve MSMEs' understanding of credit guarantee products and predict asymmetric risks. Companies can also use various media to provide knowledge about credit guarantees and their products, such as social media, as well as understand the benefits of credit guarantees. The education provided to small, medium and micro businesses can also make them understand when writing a 
business plan and make people understand the ways of getting capital from banks.

WT (Weakness-Threats) strategy provides another internal risk control strategy for credit guarantee companies. The Company implements this strategy by identifying and evaluating the internal credit guarantee process to address the company's weaknesses. This identification relates to the company's need for capabilities and expertise of the types of risks facing the company, including operational risks that can improve the company's productivity, credit guarantee risk, and liquidity risk. Risk control is also carried out by evaluating the cost of guarantee based on the level of risk carried out by the company (Dharma and Yudi, 2019). In addition, this risk control strategy can be carried out by increasing the role of credit analysts in assessing the feasibility of credit guarantees provided (Anwar and Pranoto, 2015).
Then according to its strategic priorities, it uses the QSPM matrix to calculate the importance weight and attractiveness score level (AS), as well as ranking alternative strategies that have been compiled in the SWOT matrix. QSPM matrix calculation results show that the company's main strategic focus is business risk mitigation/control, with a total attractiveness score of 5,891. The other strategies sequentially are increase the company capital $(5,695)$, cooperation with other institutions related to credit guarantee $(5,433)$, increase the adaptation of information technology devices $(5,285)$, provide assistance and consulting to MSMEs (5,241), product development $(5,203)$. The lowest strategic focus is the market development strategy $(5,105)$. Credit guarantee company alternatives strategy of Jamkrida Riau is presented in Figure 3.

Figure 3. SWOT analysis matrix of Jamkrida Riau

\begin{tabular}{|c|c|c|}
\hline & Strength $(\mathrm{S})$ & Weakness (W) \\
\hline $\begin{array}{l}\text { Opportunities } \\
\text { (O) }\end{array}$ & $\begin{array}{l}\text { SO strategies } \\
\text { 1. } \quad \text { Product development strategies }(\mathrm{S} 1, \mathrm{~S} 4, \mathrm{O} 1, \mathrm{O} 2, \mathrm{O} 3, \mathrm{O} 5) \\
\text { 2. } \quad \text { Market penetration strategy }(\mathrm{S} 2, \mathrm{~S} 3, \mathrm{O} 2, \mathrm{O} 3, \mathrm{O} 4)\end{array}$ & $\begin{array}{l}\text { WO strategies } \\
\text { 1. Increased capacity of capital } \\
\text { (W1,W2,W3,W4,W5,O1,O2,O3,O4,O5) } \\
\text { 2. Increasing the adaptation of technology and } \\
\text { information (W3, W5, O4, O5) }\end{array}$ \\
\hline Threats (T) & $\begin{array}{l}\text { ST strategies } \\
\text { 1. } \begin{array}{l}\text { Cooperation of PT. Jamkrida Riau with parties related to the } \\
\text { company's efforts to control the risk (S1, S2, S3, S4, S5, T1, } \\
\text { T2, T4, T5) }\end{array} \\
\text { 2. } \begin{array}{l}\text { introduced credit guarantee products and provided assistance to } \\
\text { MSMEs (S3, S4, T3, T5) }\end{array}\end{array}$ & $\begin{array}{l}\text { WT strategies } \\
\begin{array}{l}\text { Risk prevention strategies (W1 W2 W4 T1 } \\
\text { T3 T4) }\end{array}\end{array}$ \\
\hline
\end{tabular}

The results of the analysis of the formulation and implementation of the strategy describe several internal strategic factors (strengths and weaknesses) and external strategic factors (opportunities and threats) (Annisa, 2015). Analyzing these factors then formulating alternative strategies and strategic priorities can be used as advice to improve the credit guarantee business. Based on internal factor analysis generated in SWOT analysis, company management can adopt several alternative strategies in the face of business competition. The importance of prioritizing the alternative strategy is to provide advice on the work plan that will be carried out by the management of the company. Some understandings that can be applied by the management of credit guarantee companies include:

1. The Company can prevent risk by identifying and evaluating operational aspects of credit guarantees, which include: a) guarantee standards; b) guarantee clause; c) guarantee fee (IJP) based on the assumed amount of risk. In addition, the company can strengthen the role of underwriting analysts in assessing the feasibility of allocating guarantees. To overcome the value of the guarantee is too large, Jamkrida Riau company cooperates with reguarantee / reinsurance companies to implement a joint guarantee program. 
2. Improving the company's ability to participate in capital is an important part of the company's development. The company's steps are to encourage local governments to commit to increase their capital capacity, and to establish mechanisms for external parties to participate in equity so that companies can obtain funds from outside the local government.

3. Sufficient funds can help the company in improving the credit guarantee information system that is integrated with the credit information system owned by the lending bank. Development of technology and information adaptation. The study of Andreas (2019), and Rusdiono et.al (2019) showed that the utilization of technology and information is one of the priorities in formulating a company's business strategy. It can increase productivity, saves time, provides easy access, and easy to monitoring data and information.

4. Corporate consulting activities for small and medium enterprises are expected to bring the following benefits: a) Provide education to the public about the role of Jamkrida Riau company avoids moral hazard; b) improve the ability of businesses and understanding alternative methods of funding sources; c) improving the ability of MSMEs in planning and preparing business recommendations.

5. MSME consulting and education activities can enable companies to maximize the marketing network of guarantee products from local banks and cooperatives in Riau Province to the marketing network of sub-district guarantee products, thereby expanding the marketing network of guarantee products. The market penetration strategy used to capture the large potential of MSME and cooperatives that have not yet utilized credit guarantee services in collaboration with BPR, Cooperative, Village Owned
Enterprises (BUMDES), and Financial Technology (Dharma and Yudi, 2019).

The Company can improve cooperation and services together with the Regional Device Working Unit (SKPD) and provincial and district financial institutions / cities operating in Riau Province (such as The People's Credit Bank, Cooperatives, and Commercial Banks) in order to easily obtain credit. Suitable for small and medium sized corporate loans.

\section{CONCLUSIONS}

Based on the results of Jamkrida Riau company, includes internal and external analysis (IFE and EFE matrix), SWOT and QSPM analysis (company main strength factor). Jamkrida Riau's business operations are the company's position as a Regional Owned Enterprise (BUMD), and judging by the main weaknesses of Jamkrida Riau company is a limited capital operating company. In addition, the main opportunity factor facing the company is the quality of economic growth in Riau Province, while the main threat factor facing the company is the ability to pay claims risk.

The results of internal and external matrix analysis (IE) of the company are in the position of quadrant $\mathrm{V}$, that the company is in the average position or in the status of hold and maintenance. Alternative strategies derived from SWOT matrix analysis include: 1) internal risk control in the process of credit guarantee; 2) capacity building capital participation of regional governments or other investors; 3) improve cooperation with other institutions related to credit guarantee; 4) an increase in information technology adaptation; 5) giving assistance to MSME; 6) product development of ensuring that corresponds to focus effort; 7) marketing product development.

In order to improve services and business development, the company is advised to: 1) Make efforts to increase capital resources to improve credit guarantee capabilities. The addition of 
capital is highly recommended to meet the provisions of the OJK, where a guarantee company that stands for more than five years must have a minimum interest of Rp50 billion. 2) Utilizing integrated information technology and media to facilitate the service process and become a corporate database. 3) Conducting business as a government-backed company, Jamkrida Riau company can also play an active role in providing assistance/consultation to assist MSME in improving their business capabilities and provide advice to MSME to obtain banking credit. Further research needs to be done before the evaluation stage so that the effectiveness of strategies that have been developed and can be applied can be determined in the company.

\section{Acknowledgement: None}

\section{Conflict of Interest: None}

\section{Source of Funding: None}

\section{REFERENCES}

1. Abiyyu, I., M.Najib, A Asmara. 2020. Bancassurance Business Strategy in Life Insurance: a Case Study One of Joint Venture Company in Indonesia, JDM (Jurnal Dinamika Manajemen) Volume 11, Number 1, Pages 102-114. Semarang: Universitas Negeri Semarang

2. Andreas, David. 2019. Pengembangan Model Bisnis Koperasi Serba Usaha Pinto Jaya. Thesis. Bogor: Institut Pertanian Bogor.

3. An-nisa, NS, R. Syarief, G. Suprayitno. 2015. Strategi pengembangan asuransi ternak sapi. Jurnal Manajemen \& Agribisnis, Volume 12, Number 1, Pages 27-35. Bogor: Institut Pertanian Bogor

4. Anwar, Diding $\mathrm{S}$ and $\mathrm{T}$ Pranoto. 2015. Industri Penjaminan Menatap Indonesia Gemilang. Jakarta: Lembaga Manajemen FEB UI.

5. Azharfan, Alif N and M. Ibrahim. 2020. Analisis Tingkat Kesehatan Keuangan Sebagai Analisis Kinerja Manajemen Pada PT. Jamkrida Riau Pekanbaru. JOM (Jurnal Online Mahasiswa) Volume 7, Number 2, Pages 1-16. Pekanbaru: Universitas Riau
6. Bank Indonesia. 2020. Laporan Perekonomian Provinsi Riau November 2020. Pekanbaru: Bank Indonesia.

7. Badan Pusat Statistik. 2020. Riau dalam Angka 2019. Pekanbaru: BPS Provinsi Riau.

8. David FR. 2010. Strategic Management: Manajemen Strategis Konsep edisi ke 12. Jakarta: Salemba Empat.

9. Dharma, Putra IKIS and SP Yudi. 2019. Reformulation Of Business Strategy to Increase Credit Guarantee in PT. Jamkrida Bali Mandara. Russian Journal of Agricultural and Socio-Economic Sciences, Volume 92, Number 8, Pages 89-105. Rusia: Orel.

10. Editiyanto, Rendika A. 2014. Formulasi strategi unit bisnis jasa pengiriman peralatan perbankan (studi kasus PT. Anugerah Perdana Mandiri). Thesis. Bogor: Institut Pertanian Bogor.

11. Haq, Ahmad I and ML Singgih. 2019. Business Strategy of Chemical Company Using SWOT and Business Model Canvas Approach. IPTEK Journal of Proceedings Series: The 1st International Conference on Business and Management of Technology (IConBMT), 2019. Pages 34-42.

12. Hartatik, H, and T Baroto. 2017. Strategi pengembangan bisnis dengan metode business model canvas. Jurnal Teknik Industri. Volume 18, Number 2, Pages 113120. Malang: Universitas Muhammadiyah Malang

13. Kementerian Koperasi dan UKM. 2019. Data Dukung Komisi Peningkatan Akses Pembiayaan. Jakarta: Kementerian Koperasi dan UKM.

14. Kementerian Keuangan. 2019. Progres Input Data UMKM. Pekanbaru: Kementerian Keuangan.

15. Lapod, John. (2016). Analisis Penentuan Strategi Dalam Lingkungan Bisnis Yang Kompetitif Studi Kasus Pada PT. Pelindo IV (Persero). Jurnal Riset Bisnis dan Manajemen, Volume 4, Number 1, Pages 33-48. Bandung: Universitas Pasundan

16. Nugroho, Andi, AT Haryono AT, Minarsih. 2015. Analisis Strategi Pemasaran Surety Bond Pada PT. Asuransi Raya Cabang Semarang Dengan Menggunakan Analisis SWOT. Journal of Management, Volume 1, Number 1, Pages 1-8. Semarang: Universitas Pandanaran 
17. Osterwalder, Alexander and Y Pigneur. 2010. Business Model Generation: A Handbook For Visionaries, Game Changers, And Challengers. New Jersey: John Wiley \& Sons.

18. Otoritas Jasa Keuangan. 2017. Peraturan OJK Nomor 2/POJK.05/2017. Jakarta: Otoritas Jasa Keuangan.

19. Putri, Vindaniar Y, DS Tasya, A Rahayu. 2020. SWOT analysis on credit guarantee business sector in indonesia: A Study from Jamkrindo. Journal of Economics, Business and Management 8(3):151-156. Jakarta: Universitas Indonesia

20. Rusdiono, AS, A Asmara, and Kirbrandoko. 2019. Analisis Strategi Pengembangan Bisnis PT. TAF (Toyota Astra Financial Services). Jurnal Manajemen dan Organisasi, Volume 10, Number 1, Pages24-35. Bogor: Institut Pertanian Bogor

21. Sulastri, S., A. Rifin, and B. Sanim. 2018. Strategi Pengembangan Asuransi Jiwa. Jurnal Aplikasi Bisnis dan Manajemen (JABM), Volume 4, Number 1. Pages 4450. Bogor: Institut Pertanian Bogor

22. Sulistyo B. 2017. Analisis Manajemen Strategi Perusahaan pada PT. Adira Finance. Sumber, Volume 72 Number 2. Pages 28-42. Depok: Universitas Gunadarma

23. Untoro and P. Warjiyo. 2005. Default Risk Dan Penjaminan Kredit UKM. Buletin Ekonomi Moneter dan Perbankan, Volume
7, Number 4, Pages 584-620. Jakarta: Bank Indonesia

24. Wahyu, DR and S Fatonah. 2019. Analisis Penilaian Tingkat Kesehatan PT. Jamkrida Banten Tahun 2014-2016. Banque Syar'i: Jurnal llmiah Perbankan Syariah 3(1):79112. Banten: Universitas Islam Negeri Banten.

25. Wibowo, Wahju. 2009. Analisis Internal dan Ekternal (IE) Matrik dalam Strategi Pengembangan Objek Wana Wisata Grajagan. Jurnal Ekonomi Bisnis, Volume 14, Number 2, Pages 161-170. Malang: Universitas Negeri Malang.

26. Zuleha, Siti. 2018. Model Mitigasi Risiko pada Lembaga Penjamin Kredit di Indonesia. Mimbar Hukum-Fakultas Hukum Universitas Gadjah Mada, Volume 30, Number 2, Pages 291-303. Yogyakarta: Universitas Gadjah Mada.

27. Bahri, B. (2018). Purchasing Decisions and Customer Satisfaction Are Influenced by Location Variables, Service, Product Quality, Emotional Value, and Interior Design That Impact the Purchase Rate. Maksipreneur Journal: Management, Cooperatives, And Entrepreneurship, 8(1), 60. https://doi.org/10.30588/jmp.v8i1.388

How to cite this article: Akbar JS, Suroso AI, Hasbullah R. Strategy development of regional credit guarantee company. International Journal of Research and Review. 2021; 8(4): 326-335. DOI: https://doi.org/10.52403/ijrr.20210439 